\title{
Cytogenotoxicity of rice crop water after application of the tricyclazole fungicide
}

\author{
ALANA C.D. WANDSCHEER ${ }^{1}$, ENIO MARCHESAN ${ }^{1}$, SOLANGE B. TEDESCO ${ }^{2}$, \\ VIVIANE DAL-SOUTO FRESCURA ${ }^{2}$, CAMILLE F. SOARES ${ }^{1}$, GUILHERME P. \\ LONDERO ${ }^{1}$, GUSTAVO M. TELÓ ${ }^{1}$ and DÂMARIS S.S. HANSEL ${ }^{1}$
}

\author{
${ }^{1}$ Universidade Federal de Santa Maria, Centro de Ciências Rurais, Departamento de Fitotecnia, Avenida \\ Roraima, 1000, Prédio 85, Cidade Universitária, Camobi, 97105-900 Santa Maria, RS, Brazil \\ ${ }^{2}$ Universidade Federal de Santa Maria, Centro de Ciências Naturais e Exatas, Departamento de \\ Biologia, Laboratório de Citogenética Vegetal e Genotoxicidade, Avenida Roraima, 1000, Prédio \\ 16, Sala 3111, Cidade Universitária, Camobi, 97105-900 Santa Maria, RS, Brazil
}

Manuscript received on July 17, 2015, accepted for publication on December 22, 2016

\begin{abstract}
Tricyclazole is currently one of the fungicides recommended for the treatment of diseases in irrigated rice. However, there is relatively little information on its cytotoxic and genotoxic potential. The objective of this study was to evaluate the cytotoxicity and genotoxicity of rice crop water after apllication of the tricyclazole fungicide through the Allium cepa L. test. The rice crop water samplings were collected before and 1, 15 and 30 days after application of the fungicide in rice plant shoots. The Allium cepa roots were placed in contact with the rice crop water to check for possible chromosomal abnormalities and mitotic index of the bioindicators meristematic cells. The data obtained by the Allium cepa test indicates that the application of the tricyclazole fungicide leads to an increase in the genotoxic activity in the rice crop water, through the appearance of chromosomal abnormalities, without, however, causing significant effects on the mitotic index. The major chromosomal alterations observed were anaphasic and telophasic bridges and laggard chromosomes.
\end{abstract}

Key words: bioindicator, chromosomal abnormalities, mitotic index, pesticide, irrigated rice.

\section{INTRODUCTION}

The chemical properties and concentration of pesticides applied to the environment are important factors to consider as to the harm that can be caused to the biota exposed to them. Studies have shown that some pesticides can be toxic and/or genotoxic to different organisms and influence survival, fertility and genetic composition of the populations.

Correspondence to: Enio Marchesan

E-mail: eniomarchesan@gmail.com
In this sense, knowledge about the toxicity and genotoxicity of pesticides used in Brazilian agriculture is extremely important (Krüger 2009).

One of the options to monitor the genotoxic effect of pesticides is to use plants as target organisms, since the plants are recognized as excellent genetic models on the detection of environmental mutagenic agents and, therefore, they are frequently used for biomonitoring studies. The Allium cepa $\mathrm{L}$. test is used as a system for evaluation of the mutagenicity of substances; it is a low cost and easy-to-apply 
test; besides, it has benefits over other tests that need previous preparation of tested samples and the addition of an exogenous metabolic system (Leme and Marin-Morales 2009). Radic et al. (2010) highlight that the use of plant bioassays provides numerous advantages of comparison with animal systems, because of the similarity of chromosomal morphology and the similar responses to mutagenesis. Furthermore, plant systems are less expensive and can be conducted in less time.

The A. cepa test consists of a method of chromosomal alterations in onion roots; it is very effective in analyzing and monitoring the genotoxicity of environmental substances in situ. It is a method validated by the Sistema Internacional de Segurança Química and by the United Nations Environment Programme (UNEP) (Bagatini et al. 2007).

Tedesco and Laughinghouse IV (2012) highlighted that mutagens can be detected cytologically by cell division inhibition, chromosomal breakage in metaphase, induction of structural and numerical alterations, varying from chromosomal fragmentation to disruption of mitotic spindle. Thus, studies that enable the evaluation of genotoxicity of components present in the environment, whether industrial waste, pesticides, residues or even vegetal infusions, is extremely important and can easily be analyzed by the $A$. cepa test.

The tricyclazole is a systemic fungicide from the benzothiazole chemical group that is recommended for the control of the fungus Pyricularia grisea, popularly known as rice blast, which is one of the most important diseases of rice crop. The tricyclazole fungicide is preventive and should be applied to rice crops before the panicles, spikelets and tillers are exposed to infection. The pesticide can be applied by air or backpack sprayers. Two fungicide applications are usually performed, and the second application should be made at 15 or 20 days after the first application (SOSBAI 2012,
MAPA 2015). Pesticides have been considered potential chemical mutagens and experimental data revealed that several agrochemical ingredients exhibit mutagenic properties inducing mutations, chromosomal alterations or DNA damage (Bolognesi 2003). Whereas that the knowledge of toxicity of pesticides in the environment is of great importance, the objective of this study was to evaluate the cytotoxicity and genotoxicity of rice crop water after application of the tricyclazole fungicide through the $A$. cepa test.

\section{MATERIALS AND METHODS}

The study was carried out in an experimental floodplain rice area of the Plant Science Department, Federal University of Santa Maria, during the 2012/13 season. The rice crop was sown in experimental plots with a total area of $10 \mathrm{~m}^{2}$ each ( $4 \mathrm{~m}$ long and $2.5 \mathrm{~m}$ wide), isolated by levees (barrier composed by soil against water mixture) with individual irrigation and drainage. Each experimental plot was composed of one treatment in the field. In the first experimental plot, there was a single application of fungicide containing the active ingredient tricyclazole at the dose of 300 grams of the pesticide per hectare (225 grams of the active ingredient per hectare) on the rice shoots, when the crop was at the $\mathrm{R} 2$ reproductive stage (collar formation on flag leaf), according to the scale of Counce et al. (2000); in the second experimental plot, no pesticides were applied during the entire cultivation. The application of pesticide was done with a $\mathrm{CO}_{2}$ pressurized backpack sprayer using 150 $\mathrm{L} \mathrm{ha}^{-1}$ of spraying volume attached to a spray boom with five hollow cone nozzles (Jacto JA-2) spaced $0.50 \mathrm{~m}$ and operating at $276 \mathrm{kPa}$.

The cultivar used was PUITA INTA CL, seeded at a density of $85 \mathrm{~kg} \mathrm{ha}^{-1}$ seed, in the minimum tillage system. Fertilization, side dressing nitrogen fertilization, the beginning of irrigation and other cultural practices were conducted according to 
soil analysis and technical recommendations for irrigated rice (SOSBAI 2012).

The experiments with the Allium cepa test were carried out in the Laboratory of Plant Cytogenetics and Genotoxicity, Federal University of Santa Maria. For this purpose, water from experimental plots was collected at four times: 24 hours before fungicide application ( 0 day), 1 day, 15 days and 30 days after fungicide application. The cytogenotoxicity of the rice crop water was tested in each sampling through the $A$. cepa test by assessing changes in the mitotic index and chromosomal structure.

For each water sampling day, four treatments were evaluated: T1: distilled water (negative control); T2: glyphosate at 3\% (positive control); T3: rice crop water (water from experimental plots where no pesticides were applied); T4: rice crop water + tricyclazole (water from experimental plot with application of tricyclazole).

The experimental design was completely randomized with three replications (onion bulbs) per treatment. The bulbs were placed in distilled water for a period of 72 hours at room temperature and afterwards they were transferred to testsolutions for a period of 24 hours.

After the period of root exposure to the $A$. cepa treatments, the bulbs were removed from the testsolutions and the roots were collected and fixed in 3:1 (ethanol: acetic acid) for a 24-hour period at room temperature and stored in $70 \%$ ethanol under refrigeration. For the preparation of slides, the roots were removed from the $70 \%$ ethanol, rinsed in distilled water and only the $5 \mathrm{~mm}$ rootlets were separated for the slides; they were hydrolyzed with $1 \mathrm{~N} \mathrm{HCl}$ for 5 minutes, rinsed again in distilled water and stained with $2 \%$ orcein-acetic, using the crushing technique (Guerra and Souza 2002).

Two slides were prepared for each bulb. The slides were observed under a microscope and analyzed. The total number of cells in interphase and mitotic was counted and the mitotic index (MI) was calculated through the formula: (number of cells in prophase + number of cells in metaphase + number of cells in anaphase + number of cells in telophase) / total number of cells observed (Sehgal et al. 2006). A total of 3000 cells were counted per treatment, and 1000 cells per bulb were analyzed.

The mitotic index data was subjected to pairwise comparisons using Tukey's Test and an overall risk level of $5 \%$. The chromosomal alterations were expressed as percentages of the total cells in cell division.

\section{RESULTS AND DISCUSSION}

The cytotoxicity and genotoxicity of rice crop water before and after application of tricyclazole was analyzed using the $A$. серa test. Considering that the mitotic index is used as a biological indicator of appropriate cell proliferation (Gadano et al. 2002), which can be measured through the $A$. cepa test (Tedesco and Laughinghouse IV 2012), it can be inferred that the application of tricyclazole did not cause significant changes in the mitotic index of $A$. cepa $\mathrm{L}$., since the mitotic index values were similar to those if the laboratory control (distilled water) or the field control (rice crop water) for all sampling days (Table I).

We observed that on the $1^{\text {st }}$ day (1 day after tricyclazole application), the mitotic index of rice crop water + tricyclazole (T4) was $4.7 \%$ and did not differ from rice crop water (T3) and distilled water (T1) with $\mathrm{MI}=5.43 \%$ and $5 \%$, respectively. Similar behavior was observed for the $15^{\text {th }}$ day and the $30^{\text {th }}$ day after fungicide application, where the treatment $\mathrm{T} 4$ presented a similar mitotic index to that of rice crop water $(\mathrm{MI}=3.87 \%$ and $3.4 \%$, respectively) and similar to that of distilled water (MI $=3.3 \%$ and $3.77 \%$, respectively).

As far as chromosomal abnormalities are concerned, it was found that the rice crop water without fungicide application showed antiproliferative properties which can be observed 
TABLE I

Number of Allium cepa cells at the interphase and mitosis stages. Santa Maria, 2014.

\begin{tabular}{|c|c|c|c|c|c|c|c|}
\hline Day & Treatment & Interphase & Prophase & Metaphase & Anaphase & Telophase & MI (\%) \\
\hline & $\mathrm{T} 1$ & 2854 & 46 & 46 & 28 & 26 & $4.87 \mathrm{~b}$ \\
\hline \multirow[t]{4}{*}{0} & $\mathrm{~T} 2$ & 2916 & 35 & 33 & 10 & 6 & $2.8 \mathrm{c}$ \\
\hline & $\mathrm{T} 3$ & 2821 & 86 & 49 & 26 & 18 & $5.97 \mathrm{a}$ \\
\hline & $\mathrm{T} 4$ & - & - & - & - & - & - \\
\hline & CV (\%) & & & & & & 7.74 \\
\hline \multirow[t]{5}{*}{1} & $\mathrm{~T} 1$ & 2850 & 66 & 34 & 12 & 38 & $5 \mathrm{a}$ \\
\hline & $\mathrm{T} 2$ & 2937 & 30 & 14 & 8 & 11 & $2.1 \mathrm{~b}$ \\
\hline & $\mathrm{T} 3$ & 2837 & 64 & 61 & 22 & 16 & $5.43 \mathrm{a}$ \\
\hline & $\mathrm{T} 4$ & 2859 & 66 & 26 & 22 & 27 & $4.7 \mathrm{a}$ \\
\hline & CV (\%) & & & & & & 16.02 \\
\hline \multirow[t]{5}{*}{15} & $\mathrm{~T} 1$ & 2786 & 116 & 46 & 24 & 28 & $7.13 \mathrm{a}$ \\
\hline & $\mathrm{T} 2$ & 2988 & 7 & 2 & 0 & 3 & $0.4 \mathrm{c}$ \\
\hline & $\mathrm{T} 3$ & 2898 & 36 & 27 & 19 & 20 & $3.4 \mathrm{~b}$ \\
\hline & $\mathrm{T} 4$ & 2884 & 51 & 35 & 17 & 13 & $3.87 \mathrm{~b}$ \\
\hline & CV (\%) & & & & & & 9.11 \\
\hline \multirow[t]{5}{*}{30} & $\mathrm{~T} 1$ & 2887 & 38 & 28 & 25 & 22 & $3.77 \mathrm{a}$ \\
\hline & $\mathrm{T} 2$ & 2971 & 13 & 7 & 3 & 6 & $0.97 \mathrm{c}$ \\
\hline & $\mathrm{T} 3$ & 2930 & 27 & 24 & 11 & 8 & $2.33 \mathrm{~b}$ \\
\hline & $\mathrm{T} 4$ & 2901 & 49 & 24 & 13 & 13 & $3.3 \mathrm{a}$ \\
\hline & CV (\%) & & & & & & 12.35 \\
\hline
\end{tabular}

(0): 24 hours before application of fungicide; (1): 24 hours after application of fungicide; (15): 15 days after application of fungicide; (30): 30 days after application of fungicide; (T1): distilled water; (T2): glyphosate at 3\%; (T3): rice crop water; (T4): rice crop water + tricyclazole; $(\mathrm{MI})$ : mitotic index; $(\mathrm{CV})$ : coefficient of variation. The same letters in the column do not differ by Tukey test at $5 \%$ error probability.

on the $15^{\text {th }}$ day and the $30^{\text {th }}$ day (Table I). This phenomenon may be associated with the complex environment of rice crops, since rice irrigation water usually comes from water reservoirs, which may contain residues of compounds that have been leached from other places and reached the crops through a water stream, or products from organic decomposition that can exhibit cytotoxic and genotoxic action on sensitive bioindicator organisms such as $A$. cepa.

Currently, there is great concern about the final destination of rice crop water due to the contamination of lakes, rivers and groundwater, since rice crop is preferably cultivated close to water sources. Besides, an irrigated rice crop is an important habitat for a variety of animals, especially invertebrates, which develop part of their aquatic life cycle in the wet environment of rice crops (Bambaradeniya et al. 2004). These organisms can be exposed to agents capable of inducing chromosomal abnormalities, which may result in the development of cancer or cell death processes (Bagatini et al. 2009, Costa and Menk 2000) or harm the vital process of cells such as genetic material duplication and genetic transcription (Costa and Menk 2000).

Fisun and Rasgele (2009) stressed that the decrease in mitotic index can be used as assessment 
of cytotoxicity. However, mutagenic effects result in chromosomal abnormalities that can be detected during the cell cycle through cytogenetic analysis. The genotoxicity reviews mainly include DNA damage, mutations and chromosomal alterations (Tedesco and Laughinghouse IV 2012). Thus, the structural and/or numerical analysis of chromosomal alterations can significantly contribute the interpretation of the effects of chemical compounds to the environment.

In this study, there were genotoxic effects in rice crop water before fungicide application; however, with a lower percentage compared to the values obtained after applying tricyclazole. There was an increase in the percentage of chromosomal abnormalities present in rice crop water after applying tricyclazole, which was detected by the $A$. cepa test up to 30 days after application (Table II).
The observed chromosomal alteration values ranged from $19.83 \%$ to $22.22 \%$ in the treatment containing rice crop water + tricyclazole, and when these values are compared with those observed for rice crop water without fungicide application, the values ranged from $11.04 \%$ to $16.67 \%$, showing the effect of the fungicide on the cell cycle of $A$. cepa. The observed changes, such as telophasic and anaphasic bridges, appeared in greater numbers after applying the fungicide on all sampling days $\left(1^{\text {st }}, 15^{\text {th }}\right.$ and $30^{\text {th }}$ days), which consequently led to the appearance of micronuclei observed after the arrival of the chromosomes at the cell poles (Table II).

The onions exposed to negative control at the laboratory (T1) showed low percentage of chromosomal abnormalities, ranging from $0.93 \%$ to $4.1 \%$ (Table II). Although A. cepa chromosomal

TABLE II

Number of Allium cepa cells in cell division and chromosomal abnormalities. Santa Maria, 2014.

\begin{tabular}{|c|c|c|c|c|c|c|c|c|}
\hline Day & Treatment & CD & ATB & $\mathbf{L C}$ & MC & BC & CA (n) & $\begin{array}{l}\text { CA } \\
(\%)\end{array}$ \\
\hline & $\mathrm{T} 1$ & 146 & 6 & 0 & 0 & 0 & 6 & 4.1 \\
\hline \multirow[t]{3}{*}{0} & $\mathrm{~T} 2$ & 84 & 4 & 0 & 0 & 0 & 4 & 4.76 \\
\hline & $\mathrm{T} 3$ & 179 & 5 & 3 & 0 & 0 & 8 & 4.47 \\
\hline & $\mathrm{T} 4$ & - & - & - & - & - & - & - \\
\hline \multirow[t]{4}{*}{1} & $\mathrm{~T} 1$ & 150 & 0 & 0 & 0 & 0 & 0 & 0 \\
\hline & $\mathrm{T} 2$ & 63 & 9 & 4 & 5 & 3 & 21 & 33.33 \\
\hline & $\mathrm{T} 3$ & 163 & 4 & 11 & 1 & 2 & 18 & 11.04 \\
\hline & $\mathrm{T} 4$ & 141 & 11 & 7 & 8 & 2 & 28 & 19.86 \\
\hline \multirow[t]{4}{*}{15} & $\mathrm{~T} 1$ & 214 & 2 & 0 & 0 & 0 & 2 & 0.93 \\
\hline & $\mathrm{T} 2$ & 12 & 0 & 1 & 0 & 7 & 8 & 66.67 \\
\hline & $\mathrm{T} 3$ & 102 & 4 & 8 & 2 & 3 & 17 & 16.67 \\
\hline & $\mathrm{T} 4$ & 116 & 6 & 11 & 2 & 4 & 23 & 19.83 \\
\hline \multirow[t]{4}{*}{30} & $\mathrm{~T} 1$ & 113 & 1 & 3 & 0 & 0 & 4 & 3.54 \\
\hline & $\mathrm{T} 2$ & 29 & 3 & 6 & 2 & 7 & 18 & 62 \\
\hline & $\mathrm{T} 3$ & 70 & 2 & 5 & 1 & 1 & 9 & 12.86 \\
\hline & $\mathrm{T} 4$ & 99 & 3 & 8 & 5 & 6 & 22 & 22.22 \\
\hline
\end{tabular}

(0): 24 hours before application of fungicide; (1): 24 hours after application of fungicide; (15): 15 days after application of fungicide; (30): 30 days after application of fungicide; (T1): distilled water; (T2): glyphosate at 3\%; (T3): rice crop water; (T4): rice crop water + tricyclazole; CD: Number of cells showing regular division; ATB: anaphasic and telophasic bridges; LC: laggard chromosomal; MC: micronuclei cell; BC: binucleate cell; CA (n): number of chromosomal abnormalities; CA (\%): \% of chromosomal abnormalities in relation to the number of dividing cells. 
abnormalities in cells exposed to distilled water is not a frequent event, this result may be found in some tests. Similar results were observed by Machado et al. (2012), where 4\% of chromosomal abnormalities were found in A. cepa root cells after exposure to the negative control treatment with distilled water, compared to $27 \%$ of chromosomal alterations found in diluted wastewater treatment. Likewise, Ping et al. (2012) found $0.17 \%$ of chromosomal abnormalities in cells exposed to $A$. cepa roots treated with distilled water.

Among the chromosomal abnormalities observed in the A. cepa test, we found anaphasic and telophasic bridges, laggard chromosomes, micronuclei and binucleate cells (Figure 1). In the rice crop water + tricyclazole treatment, we observed a greater number of anaphasic and telophasic bridges and laggard chromosomes compared to other alterations.

During mitosis, the chromosomes in metaphase are arranged in the central region of the cell, where sister chromatids can migrate to opposite poles of the cell because of the centromeres, resulting in cytokinesis, which divides the original cell into two more genetically identical cells (Bagatini et al. 2009). The alterations observed in this study may be explained by the fact that chromosomal breakage is one the major cytogenetic alterations in metaphasic cells. When the cell is in anaphase and there is a genotoxic effect, the disorganization of the mitotic spindle may occur, causing anaphasic bridges or micronuclei formation in telophase cells (Fiskesjö 1993, El-Shahaby et al. 2003).

The tricyclazole (benzothiazole $\mathrm{C}_{9} \mathrm{H}_{7} \mathrm{~N}_{3} \mathrm{~S}, \log$ Kow 1.42) is a systemic fungicide with limited information about transport and fate in rice fields (Phong et al. 2009). One of the few studies was performed by Padovani et al. (2006), who detected tricyclazole residues in water samples after rice harvest, and also noted that variables such as season and year are important factors in determining the distribution of tricyclazole residues. The authors highlighted that there is high persistence of tricyclazole in the water - soil system, with a half-life of 4 to 17 months under laboratory conditions and 6 months under field conditions, as it is not easily hydrolyzed in the environment. However, Phong et al. (2009) detected only about $2 \%$ of tricyclazole in rice crop water one day after application. The authors stressed that although the photodegradation of tricyclazole is lower compared to other compounds, it can interfere in the degradation of the product in the environment. Also, different soil properties, besides the organic material, may result in higher or lower degradation of the product.

Studies were developed under laboratory conditions to verify the physiological and toxicological effects of tricyclazole on animal species. Sancho et al. (2009) observed that tricyclazole increased the levels of triglycerides, cholesterol, glucose and lactate in fish species Danio rero. In the other hand, Rossaro and Cortesi (2013) observed that tricyclazole showed low toxicity on benthic macroinvertebrates in laboratory tests of acute toxicity. However, assessments of the cytogenotoxicity of rice crop water after application of tricyclazole are scarce; moreover, there are relatively few works in real field conditions, because it is very difficult to understand interactions that exist between chemical and physical factors, and biological agents that act on the ecosystem. In the present study, the data obtained by the Allium cepa test (in vivo model plant) indicates that tricyclazole showed a moderate toxicity causing an increase of the genotoxic activity in rice crop water through the appearance of chromosomal alterations, without significant effects on the mitotic index. However, the understanding of the interactions among the various factors involved can support decisions about sustainable management, thus avoiding the use of compounds with cytogenotoxic action and prioritizing substances with less environmental impact. 

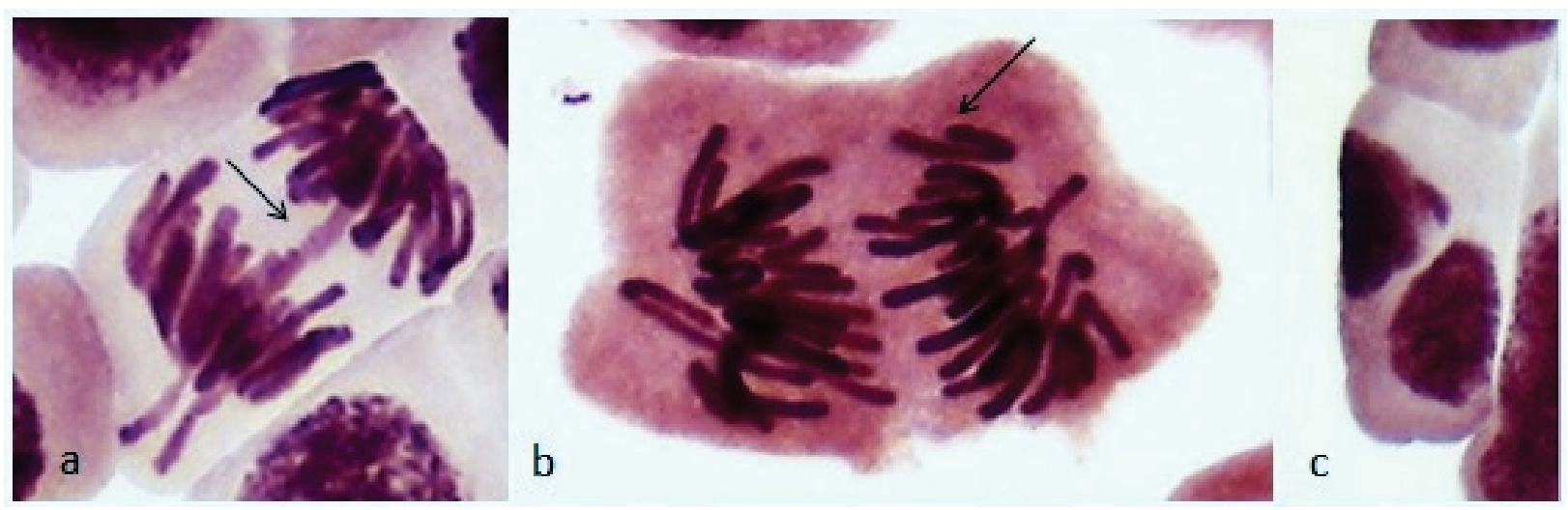

Figure 1 - Chromosomal abnormalities observed in Allium cepa cells after application of tricyclazole. (a): anaphasic bridges (b): laggard chromosomal (c): binucleate cell. Santa Maria, 2014.

\section{ACKNOWLEDGMENTS}

The authors would like to thank Coordenação de Aperfeiçoamento de Pessoal de Nível Superior (CAPES) and Conselho Nacional de Desenvolvimento Científico e Tecnológico (CNPq) for financial support (Projeto Universal No 14/2012).

\section{REFERENCES}

BAGATINI MD, DA SILVA ACF AND TEDESCO SB. 2007. Uso do sistema teste de Allium cepa como bioindicador de genotoxicidade de infusões de plantas medicinais. Rev Bras Farmacogn 17: 444-447.

BAGATINI MD, VASCONCELOS TG, LAUGHINGHOUSE IV HD, MARTINS AF AND TEDESCO SB. 2009. Biomonitoring hospital eflrents by the Allium cepa L. test. Bull Environ Contam Toxicol 82: 590-592.

BAMBARADENIYA CNB, EDIRISINGHE JP, DE SILVA DN, GUNATILLEKE CVS, RANAWANA KB AND WIJEKOON S. 2004. Biodiversity associated with an irrigated rice agro-ecosystem in Sri Lanka. Biodiversity Conserv 13: 1715-1753.

BOLOGNESI C. 2003. Genotoxicity of pesticides: a review of human biomonitoring studies. Mutat Res 543: 251-272.

COSTA RMA AND MENK CFM. 2000. Biomonitoramento de mutagênese ambiental. Biotecnologia Ciênc Desenvolv 2: 24-26.

COUNCE PA, KEISLING TC AND MITCHELL AJ. 2000. A uniform, objective, and adaptive system for expressing rice development. Crop Sci 40: 436-443.
EL-SHAHABY AO, ABDEL MIGID HM, SOLIMAN MI AND MASHALY IA. 2003. Genotoxicity screening of industrial wastewater using the Allium cepa chromosome aberration assay. Pak J Biol Sci 6: 23-28.

FISKESJÖ G. 1993. The Allium test in wastewater monitoring. Environ Toxic Water 8: 291-298.

FISUN K AND RASGELE PG. 2009. Genotoxic Effects of Raxil on Root Tips and Anthers of Allium cepa L. Caryologia 62: 1-9.

GADANO A, GURNI A, LÓPEZ P, FERRARO G AND CARBALLO M. 2002. In vitro genotoxic evaluation of the medicinal plant Chenopodium ambrosioides L. J Ethnopharmacol 81: 11-16.

GUERRA M AND SOUZA MJ. 2002. Como observar cromossomos: um guia de técnicas em citogenética em citogenética vegetal, animal e humana. Ribeirão Preto: FUNPEC, $191 \mathrm{p}$.

KRÜGER RA. 2009. Análise da toxicidade e da genotoxicidade de agrotóxicos utilizados na agricultura utilizando bioensaios com Allium cepa. 58 f. Dissertação (Mestrado em Qualidade Ambiental) - Centro Universitário Feevale. (Unpublished).

LEME DM AND MARIN-MORALES MA. 2009. Allium cepa test in environmental monitoring: A review on its application. Mutat Res 682: 71-81.

MACHADO EL, DAMBROS V, KIST LT, ACAYAGA EAL, TEDESCO SB AND MORO CC. 2012. Use of Ozonization for the Treatment of Dye Wastewaters containing Rhodamine B in the Agate Industry. Water, Air Pollut 223: 1753-1764.

MAPA - MINISTÉRIO DA AGRICULTURA E PECUÁRIA. 2015. Agrofit. Disponível em: < http://www.agricultura. gov.br/servicos-e-sistemas/sistemas/agrofit $>$. Acesso em: 20 abril. 2015. 
PADOVANI L, CAPRI E, PADOVANI C, PUGLISI E AND TREVISAN M. 2006. Monitoring tricyclazole residues in rice paddy watersheds. Chemosphere 62: 303-314.

PHONG TK, NHUNG DTT, MOTOBAYAHI T, THUYET DQ AND WATANABE H. 2009. Fate and transport of nurserybox-applied tricyclazole and imidacloprid in paddy fields. Water, Air Pollut 202: 3-12.

PING KY, DARAH I, YUSUF UK, YENG C AND SASIDHARAN S. 2012. Genotoxicity of Euphorbia hirta: An Allium cepa Assay. Molecules 17: 7782-7791.

RADIĆ S, STIPANIČEV D, VUJČIĆ V, RAJČIĆ MM, ŠIRAC S AND PEVALEK-KOZLINA B. 2010. The evaluation of surface and wastewater genotoxicity using the Allium cepa test. Sci Total Environ 408: 1228-1233.

ROSSARO B AND CORTESI P. 2013. The effects of tricyclazole treatment on aquatic macroinvertebrates in the field and in laboratory. Journal of Entomological and Acarological Research 45: 128-136.
SANCHO E, FERNÁNDEZ-VEGA C, VILLARROEL MJ, ANDREU-MOLINER E AND FERRANDO MD. 2009. Physiological effects of tricyclazole on zebrafish (Danio rerio) and post-exposure recovery. Comp Biochem Physiol C 150: 25-32.

SEHGAL R, ROY S AND KUMAR DVL. 2006. Evaluation of cytotoxic potential of latex of Calotropis procera and Podophyllotoxin in Allium cepa root model. Biocell 30: 9-13.

SOSBAI - SOCIEDADE SUL-BRASILEIRA DE ARROZ IRRIGADO. 2012. Arroz irrigado: Recomendações técnicas da pesquisa para o Sul do Brasil. Reunião Téenica da Cultura do Arroz Irrigado, 29, Gravatal, 176 p.

TEDESCO SB AND LAUGHINGHOUSE IV HD. 2012. Bioindicator of Genotoxicity: The Allium cepa Test. Environmental Contamination, Dr. Jatin Srivastava (Ed), ISBN: 978-953-51-0120-8, InTech. Disponível em: <http:// www.intechopen.com/books/environmental-contamination/ bioindicator-ofgenotoxicitythe- allium-cepa-test $>$. 